\title{
Epidemiology of paraneoplastic neurologic syndromes and autoimmune encephalitides in France
}

Julien Hébert, MDCM, MSc, Benjamin Riche, PhD, Alberto Vogrig, MD, Sergio Muñiz-Castrillo, MD, Bastien Joubert, MD, Géraldine Picard, MSc, Véronique Rogemond, PhD, Dimitri Psimaras, MD, Agusti Alentorn, MD, PhD, Giulia Berzero, MD, Virginie Desestret, MD, PhD, Muriel Rabilloud, MD, PhD, and Jérôme Honnorat, MD, PhD

Neurol Neuroimmunol Neuroinflamm 2020;7:e883. doi:10.1212/NXI.0000000000000883

\section{Abstract \\ Objective}

To determine the observed and expected incidence rates of paraneoplastic neurologic syndromes (PNSs) and autoimmune encephalitides (AEs) diagnosed in France between 2016 and 2018, we conducted a population-based epidemiologic study.

\section{Methods}

Observed incidence rates were stratified by sex, age groups, region of care, year of diagnosis, and disease subgroups. National expected incidence rates were calculated based on rates obtained in the area directly adjacent to the Reference Center using a mixed Poisson model and compared with observed incidence rates.

\section{Results}

Six hundred thirty-two patients with definite PNS or AE met the inclusion criteria. The observed incidence rate of definite PNS and AE in France was 3.2 per million person-years ( $\mathrm{CI}_{95 \%}$ : 2.9-3.4) compared with an expected incidence rate of 7.1 per million person-years ( $\mathrm{CI}_{95 \%}$ : 3.9-11.4). The national observed incidence rate for the antibody-positive $\mathrm{AE}$ subgroup increased from 1.4 per million person-years $\left(\mathrm{CI}_{95 \%}: 1.2-1.7\right)$ in 2016 to 2.1 per million personyears $\left(\mathrm{Cl}_{95 \%}\right.$ : 1.7-2.4) in 2018 , thus surpassing the incidence rate of classical PNS (1.2 per million person-years $\left.\left[\mathrm{CI}_{95 \%}: 1.0-1.5\right]\right)$ of 2018 .

\section{Conclusions}

There was a significant widespread year-to-year increase in the incidence of diagnoses registered with the Reference Center for all subgroups of PNS and AE studied. The national observed incidence rate is likely underestimated due to underdiagnosis and underreporting.

\author{
Correspondence \\ Dr. Honnorat \\ jerome.honnorat@chu-lyon.fr
}




\section{Glossary}

$\mathrm{AE}=$ autoimmune encephalitides; $\mathbf{C R C}=$ colorectal cancer; LEMS $=$ Lambert-Eaton myasthenic syndrome; PNS = paraneoplastic neurologic syndrome; SCLC $=$ small-cell lung cancer.

Paraneoplastic neurologic syndromes (PNSs) and autoimmune encephalitides (AEs) are neuroimmune disorders that are both characterized by the presence of autoantibodies that target the nervous system. ${ }^{1,2}$ Even if PNSs and AE appear to be rare, their recognition is essential because immunomodulatory treatments have been associated with marked improvements and even resolution of symptoms in a significant proportion of cases. ${ }^{3-6}$ Despite their associated human ${ }^{3}$ and economic costs, ${ }^{7}$ these neuroimmune disorders have seldom been the subject of epidemiologic studies. The annual incidence per million person-years has been estimated at 8.9 for PNS in Northeastern Italy, 5 for antibody-positive AE in Olmsted County, $\mathrm{MN},{ }^{9} 0.83$ for leucine-rich glioma inactivated 1 (LGI1) encephalitis in the Netherlands, ${ }^{10}$ and 0.9 to 2.2 for pediatric N-methyl-D-aspartic acid (NMDAr) encephalitis in the United Kingdom and Hong Kong. ${ }^{11,12}$ All of these studies have reported year-to-year increases in incidence in a context of increased diagnostic abilities and improved recognition of clinical syndromes. ${ }^{9,11,12}$

The main objective of this study was to measure the incidence of PNS and $\mathrm{AE}$ and their subgroups registered with the French National Reference Center between 2016 and 2018 inclusively. The secondary objectives were to evaluate the regional heterogeneity in incidence of declaration and quantify underreporting by providing an expected incidence rate based on the predicted rates calculated for the area surrounding the Reference Center.

\section{Methods}

\section{Population and patients}

France has a population of 66,992,699 inhabitants (source: Institut national de la statistique et des études économique [INSEE] January 1, 2019). The French National Reference Center for PNS and AE is located in Lyon, the second most populous metropolitan area of France. The Reference Center directly cares for patients diagnosed with PNS and $\mathrm{AE}$ in the surrounding Rhône-Ain-Isère region (3,798,135 inhabitants on January 1,2019). In addition to clinical care, this center provides countrywide guidance via telemedicine and antibody testing for suspected cases of PNS or AE. Although it is conceivable that patients be diagnosed locally with commercially available diagnostic panels (thus bypassing reporting to the reference center), the share of such underreporting was felt to be small and was mitigated by agreements between the Reference Center and private providers of autoimmune testing for reporting antibody-positive cases. Clinical information on patients referred to the center or obtained through our partners was collected and kept in a database onsite.
Cases from the Reference Center database diagnosed in France between January 1, 2016, and December 31, 2018, that met the following criteria were included: (1) definite $\mathrm{AE}^{2}$ except for patients with negative or atypical antibody testing, or (2) definite PNS, ${ }^{1}$ excluding cases of dermatomyositis, Lambert-Eaton myasthenic syndrome (LEMS), or with antibodies targeting P/Qtype voltage-gated calcium channel antibodies, SOX1, myelin oligodendrocyte glycoprotein, or aquaporin 4. Atypical antibody testing was defined as positive immunofluorescence with neuronal staining without target identification. Also excluded were all cases with missing biospecimens or missing information on location of care (figure e-1, links.lww.com/NXI/A308). Antibody positivity was confirmed using at least 2 different techniques (i.e., tissue-based immunofluorescence and cell-based assay or Western blot/immunodot) according to the antibody type. ${ }^{13}$ Both serum and CSF were tested whenever available. For specific antibodies (e.g., GAD65), other additional techniques (ELISA) were adopted, using serum titers $>250 \mathrm{IU} / \mathrm{mL}$ as a cutoff. ${ }^{14}$

\section{Diagnostic classification}

The cases included in this study were collectively referred to as definite PNS and AE-further emphasizing the exclusion of patients with negative/atypical antibody testing without an associated cancer. We used the following classification for subgroup analysis: (A) the PNS subgroup included patients who had a neurologic syndrome associated with a malignant tumor (including malignant thymoma but excluding teratoma) or who tested positive for a classic onconeural antibody (namely, anti-amphiphysin, -CV2/CRMP5, -Delta/Notch-like epidermal growth factor-related receptor, -Hu [ANNA1], -Ri [ANNA2], -Yo [PCA1], or -Ma2 antibody $)^{1}$; (B) the classical PNS subgroup included only patients who tested positive for one of the aforementioned typical onconeural antibodies; (C) the antibody-positive $\mathrm{AE}$ subgroup included patients with an antibody typically associated with AE (anti-AK5, -alphaamino-3-hydroxyl-5-methyl-4-isoxazolepropionic acid receptor [AMPAr], -CASPR2, -dipeptidyl-peptidase-like protein 6, -LGI1, -D2R, -gamma aminobutyric acid-A receptor, -gamma aminobutyric acid-B receptor, -glycine receptor, -immunoglobulin-like cell adhesion molecule 5, -glutamic acid decarboxylase, -glial fibrillary acidic protein, -LGI1, -mGluR1, -mGluR5, or -NMDAr antibodies ${ }^{15,16}$ ) and having 2 of the 3 following criteria ${ }^{2}$ : (1) subacute encephalopathy; (2) MRI with bitemporal $\mathrm{T} 2$ fluid attenuated inversion recovery abnormalities; and (3) CSF pleocytosis or EEG with epileptic or slowwave activity involving the temporal lobes; and (D), (E), and (F) subgroups included patients who tested positive for, respectively, anti-NMDAr, -LGI1, and -Hu antibodies. Patients who tested positive for an $\mathrm{AE}$ antibody and were diagnosed with a concomitant cancer were referred to as paraneoplastic $\mathrm{AE}$ and were included concurrently into the PNS and antibody-positive 
AE subgroups. All cancer diagnoses included occurred within 5 years of symptom onset for classical PNS and 2 years for other PNS. ${ }^{1}$ For patients testing positive to more than 1 onconeural antibody, the antibody the most consistent with their clinical presentation was assigned.

\section{Patients' characteristics}

For patients included in the study, the following characteristics were extracted from the database: age, sex, associated neoplasm, region of care, year of diagnosis, and results of antibody panel testing. We then described these characteristics for each subgroup - using absolute and relative frequency for qualitative characteristics, and median and range for quantitative characteristics. We described the distribution of cases using sexage pyramids. Testing for all aforementioned antibodies was available throughout the study period, except for glial fibrillary acidic protein, which became available in 2017 .

\section{Estimate and modeling of incidence rates}

We stratified the cases and corresponding population strata by sex, age group, region of care, and year of diagnosis. We then calculated the person-years spent at risk-the average size of the population estimated between January 1st of that year and the following year ${ }^{17}$-in each stratum using population data from the INSEE. We used the region of care as a surrogate for region of residence. Because all regions of France, with the exception of Corse, can count on at least 1 tertiary care center within their borders, the tendency for patients to seek care outside of their region of residence was felt to be minimal. We tested the soundness of this premise for the Rhône-Ain-Isère region - which was assumed to have the highest rate of nonresident diagnosis due to the location of the national reference center within its walls-and we found that only $12 \%$ of the patients diagnosed within the Rhône-Ain-Isère region were nonresidents. We estimated crude incidence rates by sex, age group, region, year of diagnosis, and for the entire French population over the period 2016-2018 with 95\% CIs built using an exact method based on a Poisson distribution.

We used log-linear mixed models to model the case count according to sex and age groups. We put a random intercept on the variable region, specified an age-sex interaction as fixed effect, and used the logarithm of the number of person-years as an offset. ${ }^{18}$ To account for nonlinearity, we modeled the age effect using a cubic spline with 3 knots. ${ }^{19}$ We used the predicted relative incidence rates for the regions to quantify the interregional heterogeneity of the incidence rate taking into account the heterogeneity due to sample size variability and adjusting for sex and age. These predicted relative incidence rates corresponded to the exponential of the best linear unbiased predictors of the mixed models and were relative to the mean incidence rate. We used maps to represent the national distribution of the relative incidence rates.

We also used a model with year of diagnosis specified as fixed and random effect to investigate the effect of the variable year of diagnosis on the incidence rates.

\section{Expected number of cases and incidence rates in France}

We considered the Rhône-Ain-Isère region the reference area in terms of completeness of case declaration because of its proximity to the Reference Center. We estimated the expected number of cases of definite PNS and AE over the period 2016-2018 by applying the predicted incidence rates obtained from the mixed model for the reference area to the person-years of each stratum of the French population. We aggregated that the expected numbers of cases were by sex, 4 age groups (0-19, 20-39, 40-59, and $\geq 60$ years), and the entire French population. The expected incidence rates corresponded to the ratio of the expected number of cases to the number of person-years. We obtained $95 \%$ CIs for the expected numbers of cases and incidence rates using a biascorrected and accelerated bootstrap method.

We conducted all statistical analyses with $\mathrm{R}$ version 3.6.0 ( $\mathrm{R}$ Core Team, Vienna, 2019), using the glmmPQL function in package NLME ${ }^{18}$ for the mixed Poisson models. The packages ggplot $2,{ }^{20} \mathrm{rgdal}^{21}$ and broom $^{22}$ were used for mapping the relative incidence rates.

\section{Standard protocol approvals, registrations, and patient consents}

The Ethics Review Board of the Hospices Civils de Lyon (19-85) approved this study, which is registered with ClinicalTrials.gov (No. NCT03957616). The French Commission nationale de l'informatique et des libertés also approved the study for data collection (Commission nationale de l'informatique et des libertés [CNIL] authorization number: 19-147).

\section{Data availability}

Anonymized data will be shared by request from any qualified investigator for purposes of replicating procedures and results.

\section{Results}

\section{Definite PNS and AE}

Among 13,442 referred cases, 632 patients had a diagnosis of definite PNS or AE: $175 / 3,376$ (5.1\%) in 2016, 218/4,445 (5.0\%) in 2017, and 239/5,621 (4.3\%) in 2018. The distribution of cases showed a bimodal age distribution with a first peak at ages 15-19 years (predominantly female patients with antibody-positive $\mathrm{AE}$ ) and a second higher peak at ages 65-69 years (high proportion of males, predominantly PNS cases) (figure 1A). As hypothesized, the most commonly identified antibodies were anti-NMDAr, followed by antiLGI1, and anti-Hu (table 1; figure e-2, links.lww.com/NXI/ A309). The proportion of females among Yo-, NMDAr-, and glutamic acid decarboxylase-positive patients was significantly above $50 \%$, whereas it was below 50\% among LGI1-, Ma2-, and CASPR2-positive patients (figure 2). Fifteen (2\%) patients tested positive for 2 antibodies: 9 had dual antibodies against $\mathrm{CV} 2$ and $\mathrm{Hu}, 5$ against LGI1 and CASPR2, and 1 against CV2 and Yo. 

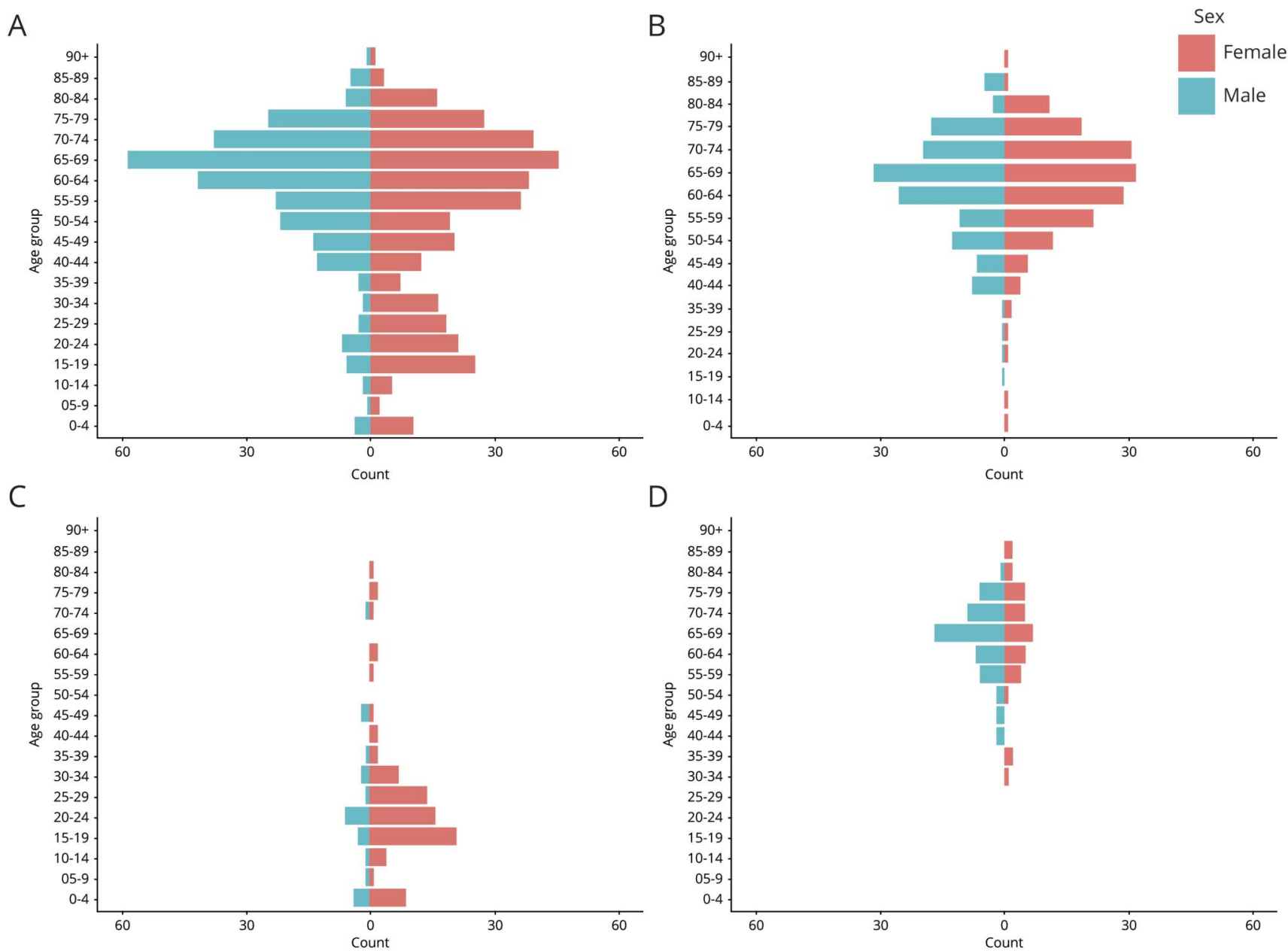

(A) Definite paraneoplastic neurologic syndromes and autoimmune encephalitides. (B) Paraneoplastic neurologic syndromes. (C) NMDAr-positive patients. (D). LGI1-positive patients.

Among the patients with definite PNS or AE diagnosis, 243 (38.4\%) had an associated diagnosis of cancer. In descending order, these cancers were lung cancer $(59 / 243,24 \%$, smallcell lung cancers [SCLCs], and 47/243, 19\%, non-small-cell lung cancers), gynecologic cancers $(34 / 243,14 \%)$, breast cancer $(29 / 243,12 \%)$, malignant thymoma $(15 / 243,6 \%)$, lymphoma $(13 / 243,5 \%)$, renal cell carcinoma $(11 / 243$, $5 \%)$, and prostate cancer $(10 / 243,4 \%)$. Less than 10 cases were found for each of leukemia, colorectal cancer (CRC), testicular, thyroid, skin, neuroendocrine, pancreatic, liver, head and neck, and bladder cancers.

The crude incidence rates of definite PNS or AE were 3.2 per million person-years $\left(\mathrm{CI}_{95 \%}\right.$ : 2.9-3.4; the incidence rates for the different subgroups are shown in table 2). For all subgroups, a yearly increase in crude incidence rates was observed. The highest crude incidence rates were seen in overseas regions of Martinique and Guadeloupe, followed by the Rhône-Ain-Isère region (table e-1, links.lww.com/NXI/A310). After modeling of incidence rates, significant regional heterogeneity remained (interregional $\mathrm{SD}=0.26$, figure 3 ). The Rhône-Ain-Isère region (site of the
National Reference Center) had the highest predicted relative incidence rate (i.e., 2 times the mean rate), followed by Aquitaine $(1.3 \mathrm{x})$ and Martinique and Guadeloupe (1.2x). The mean incidence rate increased significantly with the year of diagnosis (relative year-on-year incidence rate $=1.20 \mathrm{x}, \mathrm{CI}_{95 \%}=1.18-1.22$ ).

\section{Expected numbers of cases and incidence rates}

We estimated the crude incidence rate of definite PNS and AE in the Rhône-Ain-Isère region at 7.5 per million person-years $\left(\mathrm{CI}_{95 \%}\right.$ : 6.0-9.3). We estimated the expected number of cases in France at 1,411 $\left(\mathrm{CI}_{95 \%}\right.$ : $\left.774-2,272\right)$ and the national incidence rate of definite PNS and AE at 7.1 per million personyears $\left(\mathrm{CI}_{95 \%}\right.$ : $\left.3.9-11.4\right)$. We estimated the expected national rate of definite $\mathrm{PNS}$ and $\mathrm{AE}$ per million person-years among females at $7.7\left(\mathrm{CI}_{95 \%}\right.$ : 2.3-10.1) and 6.4 among males $\left(\mathrm{CI}_{95 \%}\right.$ : 2.6-11.9). Looking at age groups, we estimated the expected national incidence rates per million person-years at 2.5 $\left(\mathrm{CI}_{95 \%}\right.$ : 0.9-5.6) in the 0-19 age group, $3.1\left(\mathrm{CI}_{95 \%}: 1.2-6.7\right)$ in the $20-39$ age group, $8.3\left(\mathrm{CI}_{95 \%}: 3.4-16.7\right)$ in the $40-59$ age group, and $13.9\left(\mathrm{CI}_{95 \%}\right.$ : 5.5-28.9) in patients older than 60 years. 
Table 1 Patients' characteristics

\begin{tabular}{|c|c|c|c|}
\hline Characteristic & Definite PNS and AE & PNS & Antibody-positive AE \\
\hline All patients, n (\%) & 632 & 317 & 355 \\
\hline Female patients, n (\%) & $357(56.5)$ & $171(53.9)$ & $202(56.9)$ \\
\hline Age, median (range) & $62.1(0-94)$ & $65.9(0-93)$ & $54.9(0-94)$ \\
\hline Associated cancers, $\mathrm{n}(\%)^{\mathrm{a}}$ & $243(38.5)$ & $243(77 \%)$ & $40(11.3)$ \\
\hline \multicolumn{4}{|l|}{ Antibodies, n (\%) } \\
\hline Anti-NMDAr & $106(16.7)$ & $1(0.3)$ & $106(33.0)$ \\
\hline Anti-LGI1 & $85(13.3)$ & $11(3.4)$ & $85(26.5)$ \\
\hline Anti-Hu & $84(13.2)$ & $84(26.2)$ & $0(0.0)$ \\
\hline Negative/atypical & $78(12.3)$ & $78(24.3)$ & $0(0.0)$ \\
\hline Anti-GAD & $71(11.2)$ & $4(1.2)$ & $71(2.2)$ \\
\hline Anti-Yo & $37(5.9)$ & $37(11.7)$ & $0(0.0)$ \\
\hline Anti-CASPR2 & $37(5.8)$ & $9(2.8)$ & $37(11.5)$ \\
\hline Anti-CV2 & $31(4.9)$ & $31(9.7)$ & $0(0.0)$ \\
\hline Anti-GFAP & $21(3.3)$ & $1(0.6)$ & $21(6.5)$ \\
\hline Anti-Ma2 & $19(3.0)$ & $19(5.9)$ & $0(0.0)$ \\
\hline Anti-GABAbR & $18(2.8)$ & $10(5.6)$ & $18(5.6)$ \\
\hline Anti-DNER & $12(1.9)$ & $12(3.7)$ & $0(0.0)$ \\
\hline Anti-Ri & $11(1.7)$ & $11(3.4)$ & $0(0.0)$ \\
\hline Others & $22(3.5)^{\mathrm{b}}$ & $9(2.5)^{c}$ & $16(5.0)^{d}$ \\
\hline
\end{tabular}

Abbreviations: $A E$ = autoimmune encephalitis; DNER = Delta/Notch-like epidermal growth factor-related receptor; GABAbR = gamma aminobutyric acid-B receptor; GAD = glutamic acid decarboxylase; GFAP = glial fibrillary acidic protein; LGI1 = leucine-rich glioma inactivated 1; NMDAr = N-methyl-D-aspartic acid; PNS = paraneoplastic neurologic syndrome.

a Excluding 22 cases of teratomas.

${ }^{b}$ AK5: 3; AMPAr: 4; amphiphysin: 5; IgLON5: 3; mGluR1: 3; mGluR5: 1; GlyR: 1; GABAa: 1; and D2R: 1.

'AMPAR: 2; amphiphysin: 5; IgLON5: 1; and mGlur5: 1.

d AK5: 3; AMPAr: 4; GABAa: 1; GlyR: 1; IgLON5: 3; mGluR1: 3; and mGluR5: 1.

\section{Paraneoplastic neurologic syndromes}

Of the 317 patients diagnosed with PNS, 195 met the criteria for classical PNS, and 82 had atypical/negative testing for antibodies with associated cancers. Forty patients were diagnosed with paraneoplastic AE (figure e-1, links.lww.com/NXI/A308). The proportion of female patients within the PNS subgroupslightly above 50\%—remained relatively constant throughout all age groups (figure 1B). The most commonly diagnosed tumor types were lung cancer (32\% of all cancer cases), gynecologic cancer (15\%), and breast cancer (14\%).

The 70-74 age group had the highest crude incidence rate of PNS: 5.7 per million person-years $\left(\mathrm{CI}_{95 \%}\right.$ : 4.3-7.6), whereas no cases were recorded in the 5-9 age group $\left(\mathrm{CI}_{95 \%}: 0.0-0.3\right.$ per million person-years). After modeling of incidence rates, the incidence of PNS showed a significant heterogeneity between regions ( $S D$ of the distribution of the random intercept $=0.35$ ).

The antibodies detected in the classical PNS subgroup were $\mathrm{Hu}$ (84/195, 43\%), Yo (37/195, 19\%), CV2/CRMP5 (31/185, 15\%),
Ma2 (19/195, 9\%), Delta/Notch-like epidermal growth factorrelated receptor (12/195, 6\%), $\operatorname{Ri}(11 / 195,5 \%)$, and amphiphysin (5/195, 2\%). The median age of the patients with classical PNS was 66.1 years (range: $0-93$ years). Of the $84 \mathrm{Hu}$-positive cases, 43 (52\%) were female, and their median age was 66.5 years (range: 41-93 years), near the median age of the overall PNS subgroup. Cancer was present in 62 patients (74\%) of the Hu-positive subgroup: 34 SCLC, 20 NSCL, 2 prostate cancers, 1 breast cancer, 1 CRC, 1 bladder cancer, and 1 uterine cancer.

\section{Antibody-positive autoimmune encephalitis}

Within the antibody-positive $\mathrm{AE}$ subgroup, the sex distribution differed markedly according to age: while a female predominance was noted in patients younger than 50 years, males were more commonly diagnosed in patients older than 50 years. Of the 40 patients with paraneoplastic $\mathrm{AE}$ ( $11.3 \%$ of the total antibody-positive subgroup; table 1 ), there were 11 with gamma aminobutyric acid-B receptor, 11 with anti-LGI1, and 9 with CASPR2 antibodies. Compared with overall antibodypositive $\mathrm{AE}$ cases, patients with paraneoplastic $\mathrm{AE}$ were older 


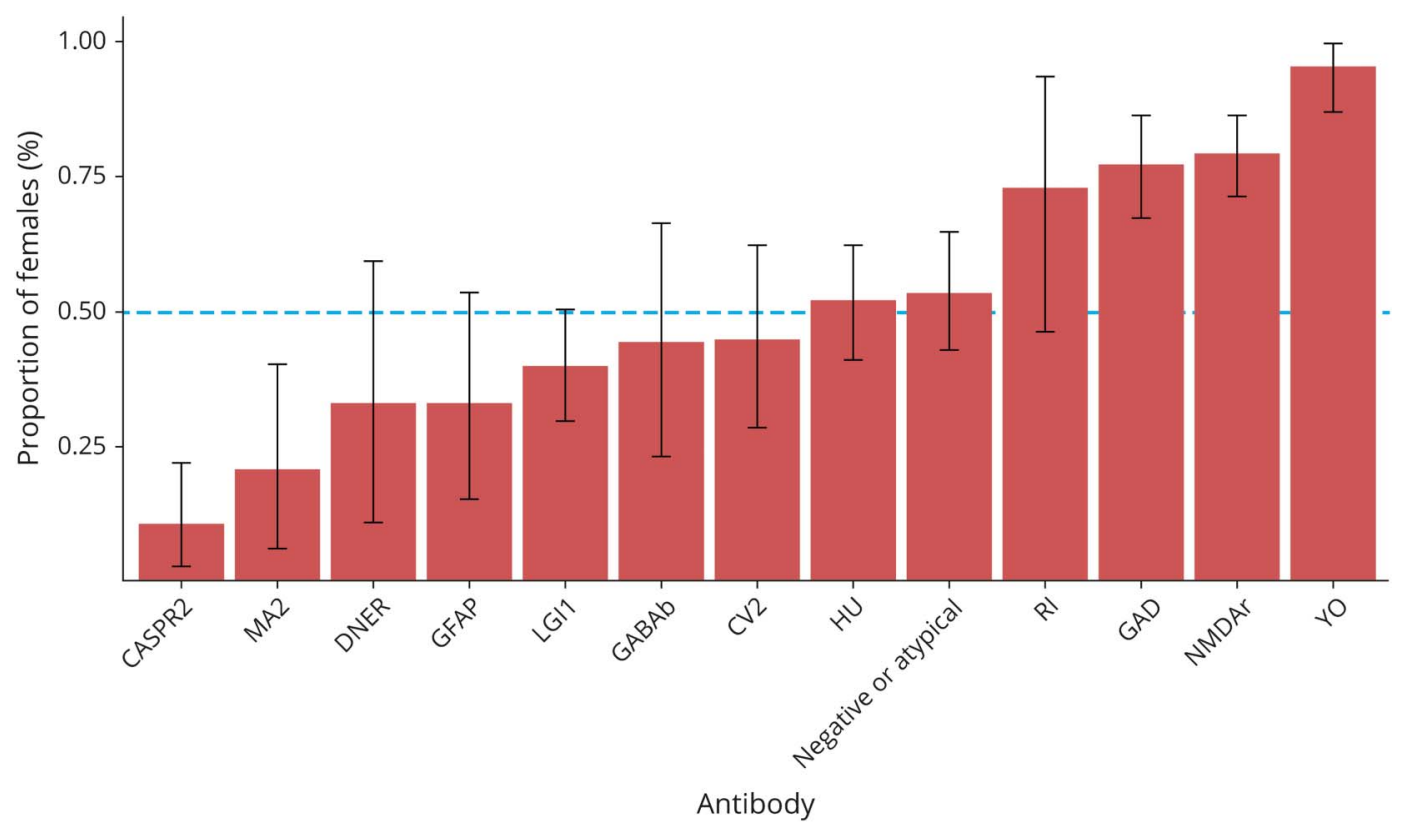

(median age: 64.8 vs 54.9 years; $p<0.001$ ) and less likely to be female $(40 \%$ vs $57 \% ; p=0.03)$. The incidence rate of antibody-positive AE again showed significant interregional heterogeneity (SD of the distribution of random intercept $=0.32)$.

The median age of the NMDAr subgroup was 22.3 years (range: $0-80$ years; figure $1 \mathrm{C}$ ), significantly lower than the median age of the whole antibody-positive AE subgroup (vs 54.9 years; $p<0.005)$. In this subgroup, $79 \%$ were females, which is also significantly higher than the percentage in the whole antibody-positive AE subgroup (57\%; $p<0.005$ ). Twenty-one cases (20\%) had teratoma, and 1 had Hodgkin lymphoma.

The LGI1-positive patients were older (median age: 67.4 vs 54.9 years; range: $33-86, p<0.001$; figure $1 \mathrm{D})$ and more likely to be males (males $=40 \%$ vs $57 \%$; $p=0.005$ ) than the whole antibody-positive AE subgroup. Only 11 cases of cancer $(13 \%)$ were found in these patients (6 malignant thymomas, 3 prostate cancer, 1 breast cancer, and 1 lung cancer).

\section{Discussion}

We report on the epidemiologic features of PNS and $\mathrm{AE}$ diagnosed on the French territory and registered with the French National Reference Center between 2016 and 2018. Despite widespread advances made in the recognition and referral of these disorders, the discrepancy between the high incidence rates observed in the immediate vicinity of the Reference Center and the rest of France suggests that underdiagnosis and underreporting still exist and highlights the need for uniform diagnostic procedures on a national scale. The regional heterogeneity in reported incidence rates may be partially explained by a combination of regiondependent underrecognition of these disorders, varying exhaustiveness in reporting, border effects with some university health centers located close to regional borders, and differences in referral patterns. Differences in regional racial composition are also a potential factor of heterogeneity: we indeed found higher crude incidence rates of definite PNS and AE in Martinique and Guadeloupe, regions with high proportions of inhabitants with African ancestry. This is akin to results by Dubey et al. ${ }^{9}$ who reported higher incidence rates of $\mathrm{AE}$ among Blacks in Olmsted County, MN. Finally, the contribution of geographic factors to regional incidence heterogeneity was felt to be minimal given the absence of clear regional clustering (figure 3).

The crude incidence rates of antibody-positive $\mathrm{AE}$ (3.6 per million person-years) and PNS (4.1 per million person-years) in Rhône-Ain-Isère region were lower than rates found in, respectively, Olmsted County (5.0 per million person-years $)^{9}$ and Northeastern Italy ( 8.9 per million person-years). ${ }^{8}$ These differences more likely reflect the increased challenge of achieving exhaustiveness in larger populations rather than true differences in incidence. Even when considering the area to the Rhone-Ain-Isère region only, the population at risk was 3,798,135 vs 155,285 for Olmsted County and 983,190 for Northeastern Italy. 8 Another potential cause of this lower incidence rate is the exclusion of patients with certain PNS (dermatomyositis and LEMS) and those harboring antibodies targeting $\mathrm{P} / \mathrm{Q}$-type voltage-gated calcium channel antibodies, SOX1, myelin oligodendrocyte glycoprotein, or aquaporin 4. 
Table 2 Incidence rates of PNS and AE in France and Rhône-Ain-Isère region, 2016 to 2018

\begin{tabular}{|c|c|c|c|c|}
\hline \multirow[b]{2}{*}{ Subgroup and period } & \multicolumn{2}{|c|}{ Whole France } & \multicolumn{2}{|c|}{ Rhône-Ain-Isère region } \\
\hline & Cases, $\mathbf{n}$ & Crude incidence $^{a}(95 \% \mathrm{Cl})$ & Cases, $\mathbf{n}$ & Crude incidence $^{\mathrm{b}}(95 \% \mathrm{Cl})$ \\
\hline \multicolumn{5}{|l|}{ Definite PNS and AE } \\
\hline 2016 & 175 & $2.6(2.3-3.1)$ & & \\
\hline 2017 & 218 & $3.3(2.9-3.7)$ & & \\
\hline 2018 & 239 & $3.6(3.1-4.1)$ & & \\
\hline $2016-2018$ & 632 & $3.2(2.9-3.4)$ & 85 & $7.5(6.0-9.3)$ \\
\hline \multicolumn{5}{|l|}{ PNS } \\
\hline 2016 & 94 & $1.4(1.1-1.7)$ & & \\
\hline 2017 & 114 & $1.7(1.4-2.0)$ & & \\
\hline 2018 & 113 & $1.7(1.4-2.0)$ & & \\
\hline 2016-2018 & 317 & $1.6(1.4-1.8)$ & 46 & $4.1(3.0-5.4)$ \\
\hline \multicolumn{5}{|l|}{ Antibody-positive AE } \\
\hline 2016 & 95 & $1.4(1.2-1.7)$ & & \\
\hline 2017 & 121 & $1.8(1.5-2.2)$ & & \\
\hline 2018 & 139 & $2.1(1.7-2.4)$ & & \\
\hline $2016-2018$ & 355 & $1.8(1.6-2.0)$ & 41 & $3.6(2.6-4.9)$ \\
\hline \multicolumn{5}{|l|}{ Classical PNS } \\
\hline 2016 & 52 & $0.8(0.6-1.0)$ & & \\
\hline 2017 & 68 & $1.0(0.8-1.2)$ & & \\
\hline 2018 & 82 & $1.2(1.0-1.5)$ & & \\
\hline 2016-2018 & 199 & $1.0(0.9-1.1)$ & 19 & $1.7(1.0-2.6)$ \\
\hline \multicolumn{5}{|l|}{$\mathrm{Hu}$} \\
\hline 2016 & 21 & $0.3(0.2-0.5)$ & & \\
\hline 2017 & 31 & $0.5(0.3-0.7)$ & & \\
\hline 2018 & 31 & $0.5(0.3-0.7)$ & & \\
\hline 2016-2018 & 83 & $0.4(0.3-0.5)$ & 11 & $1.0(0.5-1.7)$ \\
\hline \multicolumn{5}{|l|}{ NMDAr } \\
\hline 2016 & 28 & $0.4(0.3-0.6)$ & & \\
\hline 2017 & 35 & $0.5(0.4-0.7)$ & & \\
\hline 2018 & 43 & $0.6(0.5-0.9)$ & & \\
\hline $2016-2018$ & 106 & $0.5(0.4-0.6)$ & 10 & $0.9(0.4-1.6)$ \\
\hline \multicolumn{5}{|l|}{ LGI1 } \\
\hline 2016 & 24 & $0.3(0.2-0.5)$ & & \\
\hline 2017 & 23 & $0.4(0.2-0.5)$ & & \\
\hline 2018 & 38 & $0.6(0.4-0.8)$ & & \\
\hline $2016-2018$ & 85 & $0.4(0.3-0.5)$ & 7 & $0.6(0.2-1.3)$ \\
\hline
\end{tabular}

Abbreviations: $\mathrm{AE}$ = autoimmune encephalitides; LGI1 = leucine-rich glioma inactivated 1; NMDAr = N-methyl-D-aspartic acid; PNS = paraneoplastic neurologic syndrome.

a The numbers of person-years spent at risk for whole France were 66,439,735 in 2016; 66,574,069 in 2017; 66,676,327 in 2018; and 199,690,131 for period 2016-2018.

${ }^{b}$ The number of person-years spent at risk for Rhône-Ain-Isère for period 2016-2018 was 11,291,348. 
Figure 3 Maps of relative incidence rates of definite paraneoplastic neurologic syndromes and autoimmune encephalitides in France for 2016-2018
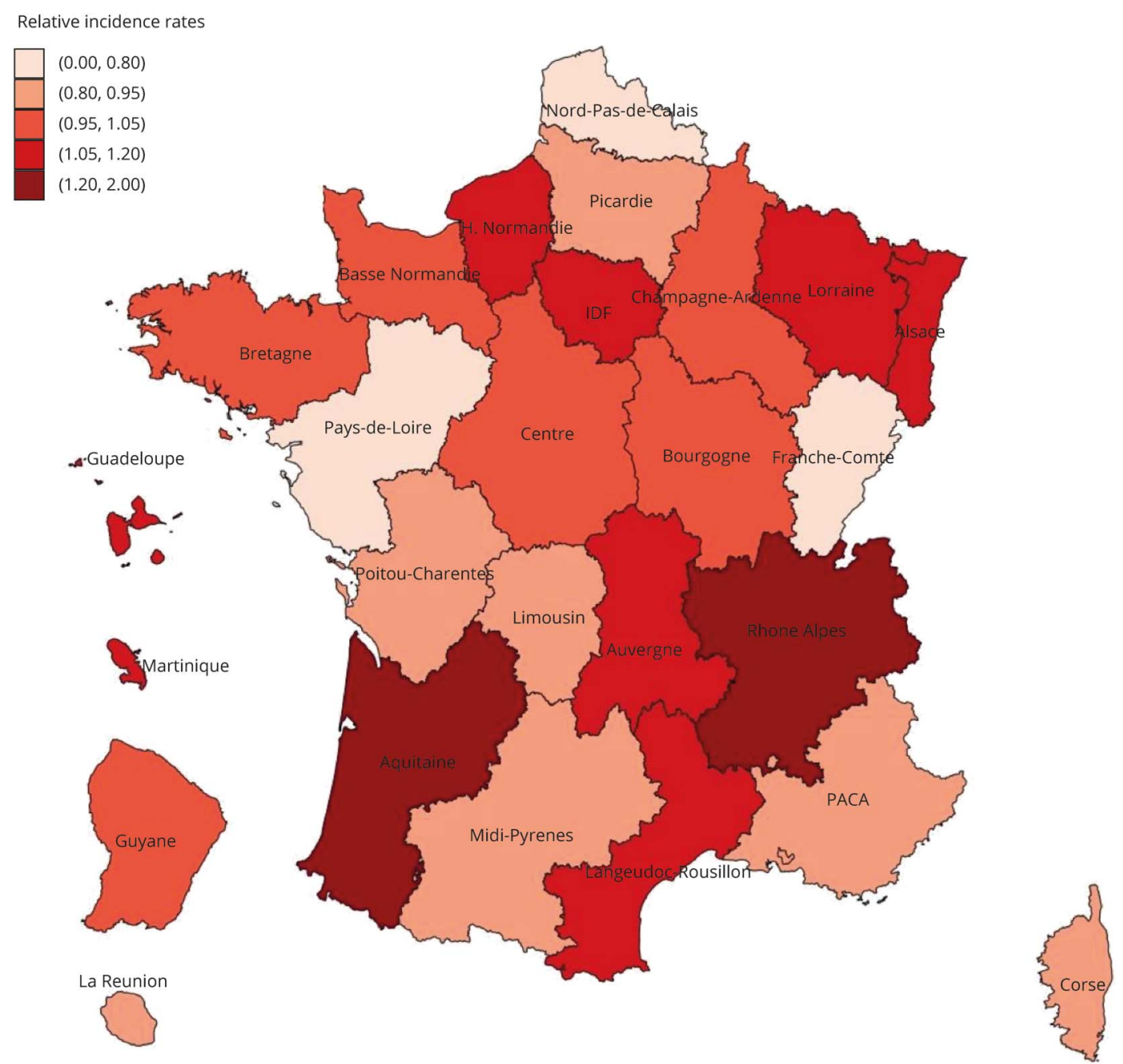

The fact that antibody-positive $\mathrm{AE}$ is now at least as commonly diagnosed as PNS suggests that there was a rapid, albeit heterogeneously distributed, heightened awareness of the condition. In fact, classical PNS-a group whose antibodies were described in the 1980s and 1990s-now represents only about a third of all definite PNS and AE cases. Part of the increased incidence seen in this subgroup may be attributable to more widespread use of immune checkpoint inhibitors in oncological practice, as already observed for specific central ${ }^{23}$ and peripheral nervous system disorders, ${ }^{24}$ including anti$\mathrm{Hu}^{25}$ and anti-Ma2-associated syndromes. ${ }^{26}$

To address the aforementioned limitations of exhaustiveness and referral patterns, future incidence studies should strengthen interhospital collaborations and ensure increased reporting of these conditions to the National Reference Center in Lyon. Including information on the location of residence of the patients would allow for a more in-depth analysis of the possible role of geographic factors on the incidence of PNS and AE.
The population-based design of this study showed a relatively accurate epidemiologic picture. We hope that this study will lead to increased recognition and reporting of these neuroimmune disorders in regions of France with lower rates of declaration, possibly through targeted educational activities. Our data will serve as a comparator for future studies of incidence of PNS and AE, monitoring their incidence in space and time-concurrently with improvements in clinicians diagnostic capabilities. ${ }^{26}$

\section{Acknowledgment}

The authors thank Jean Iwaz, $\mathrm{PhD}$, from the Hospices Civils de Lyon, Pôle Santé Publique, Service de BiostatistiqueBioinformatique (Lyon, France), and University of Lyon (Lyon, France) for his suggestions on improving the manuscript.

\section{Study funding}

This study was supported by research grants from the French Agence Nationale de la Recherche (ANR-14-CE15-0001- 
MECANO) and the Fondation pour la recherche médicale (DQ20170336751). This work was performed within BETPSY, a project supported by a public grant overseen by the French Agence Nationale de la Recherche, as part of the second Investissements d'Avenir program (ANR-18-RHUS-0012).

\section{Disclosure}

J. Hébert reports receiving a World Federation of Neurology Young Investigator Award for the work done with this manuscript. B. Riche reports no disclosures relevant to the manuscript. A. Vogrig reports receiving a fellowship grant from the European Academy of Neurology. S. Muñiz-Castrillo, B. Joubert, G. Picard, V. Rogemond, D. Psimaras, A. Alentorn, G. Berzero, V. Desestret, and M. Rabilloud report no disclosures relevant to the manuscript. J. Honnorat receives royalties from licensing fees to Athena Diagnostics, Euroimmun, and Ravo Diagnostika for a patent on the use of CV2/CRMP5 as diagnostic tests. Go to Neurology.org/NN for full disclosures.

\section{Publication history}

Received by Neurology: Neuroimmunology \& Neuroinflammation May 22, 2020. Accepted in final form July 17, 2020.

Appendix Authors

\begin{tabular}{|c|c|c|}
\hline Name & Location & Contribution \\
\hline $\begin{array}{l}\text { Julien Hébert, } \\
\text { MDCM, MSc }\end{array}$ & $\begin{array}{l}\text { Hospices Civils de Lyon, } \\
\text { Lyon, France; Université } \\
\text { Claude Bernard Lyon 1, } \\
\text { Lyon, France; Sorbonne } \\
\text { Université, Paris }\end{array}$ & $\begin{array}{l}\text { Conception and design of } \\
\text { the study; acquisition of } \\
\text { the data; analysis of the } \\
\text { data; and drafting of the } \\
\text { manuscript }\end{array}$ \\
\hline $\begin{array}{l}\text { Benjamin } \\
\text { Riche, PhD }\end{array}$ & $\begin{array}{l}\text { Hospices Civils de Lyon, } \\
\text { Lyon, France }\end{array}$ & $\begin{array}{l}\text { Conception and design of } \\
\text { the study; analysis of the } \\
\text { data; and drafting of the } \\
\text { manuscript }\end{array}$ \\
\hline $\begin{array}{l}\text { Alberto } \\
\text { Vogrig, MD }\end{array}$ & $\begin{array}{l}\text { Hospices Civils de Lyon, } \\
\text { Lyon, France; Université } \\
\text { Claude Bernard Lyon 1, } \\
\text { Lyon, France }\end{array}$ & $\begin{array}{l}\text { Acquisition of the data } \\
\text { and revision of the } \\
\text { manuscript for important } \\
\text { intellectual } \\
\text { content }\end{array}$ \\
\hline $\begin{array}{l}\text { Sergio Muñiz- } \\
\text { Castrillo, MD }\end{array}$ & $\begin{array}{l}\text { Hospices Civils de Lyon, } \\
\text { Lyon, France; Université } \\
\text { Claude Bernard Lyon 1, } \\
\text { Lyon, France }\end{array}$ & $\begin{array}{l}\text { Revision of the } \\
\text { manuscript for important } \\
\text { intellectual content }\end{array}$ \\
\hline $\begin{array}{l}\text { Bastien } \\
\text { Joubert, MD }\end{array}$ & $\begin{array}{l}\text { Hospices Civils de Lyon, } \\
\text { Lyon, France; Université } \\
\text { Claude Bernard Lyon 1, } \\
\text { Lyon, France }\end{array}$ & $\begin{array}{l}\text { Revision of the } \\
\text { manuscript for important } \\
\text { intellectual content }\end{array}$ \\
\hline $\begin{array}{l}\text { Géraldine } \\
\text { Picard, MSc }\end{array}$ & $\begin{array}{l}\text { Hospices Civils de Lyon, } \\
\text { Lyon, France; Université } \\
\text { Claude Bernard Lyon 1, } \\
\text { Lyon, France }\end{array}$ & Acquisition of the data \\
\hline $\begin{array}{l}\text { Véronique } \\
\text { Rogemond, } \\
\text { PhD }\end{array}$ & $\begin{array}{l}\text { Hospices Civils de Lyon, } \\
\text { Lyon, France; Université } \\
\text { Claude Bernard Lyon 1, } \\
\text { Lyon, France }\end{array}$ & $\begin{array}{l}\text { Acquisition of the data } \\
\text { and revision of the } \\
\text { manuscript for important } \\
\text { intellectual content }\end{array}$ \\
\hline $\begin{array}{l}\text { Dimitri } \\
\text { Psimaras, MD }\end{array}$ & $\begin{array}{l}\text { Groupe Hospitalier Pitié- } \\
\text { Salpêtrière, Paris, France; } \\
\text { Université Pierre et Marie } \\
\text { Curie-Paris 6, Paris, } \\
\text { France }\end{array}$ & $\begin{array}{l}\text { Revision of the } \\
\text { manuscript for important } \\
\text { intellectual content }\end{array}$ \\
\hline
\end{tabular}

Appendix (continued)

\begin{tabular}{lll}
\hline Name & Location & Contribution \\
\hline $\begin{array}{l}\text { Agusti } \\
\text { Alentorn, MD, } \\
\text { PhD }\end{array}$ & $\begin{array}{l}\text { Groupe Hospitalier Pitié- } \\
\text { Salpêtrière, Paris, France; } \\
\text { Université Pierre et Marie } \\
\text { Curie-Paris 6, Paris, France }\end{array}$ & $\begin{array}{l}\text { Revision of the } \\
\text { manuscript for important } \\
\text { intellectual content }\end{array}$ \\
\hline $\begin{array}{lll}\text { Giulia } \\
\text { Berzero, MD }\end{array}$ & $\begin{array}{l}\text { Groupe Hospitalier Pitié- } \\
\text { Salpêtrière, Paris, France; } \\
\text { Université Pierre et Marie } \\
\text { Curie-Paris 6, Paris, } \\
\text { France }\end{array}$ & $\begin{array}{l}\text { Revision of the } \\
\text { manuscript for important } \\
\text { intellectual content }\end{array}$ \\
\hline
\end{tabular}

\begin{tabular}{lll}
\hline $\begin{array}{l}\text { Virginie } \\
\text { Desestret, } \\
\text { MD, PhD }\end{array}$ & $\begin{array}{l}\text { Hospices Civils de Lyon, } \\
\text { Lyon, France; Université } \\
\text { Claude Bernard Lyon 1, } \\
\text { Lyon, France }\end{array}$ & $\begin{array}{l}\text { Revision of the } \\
\text { manuscript for important } \\
\text { intellectual content }\end{array}$ \\
\hline $\begin{array}{l}\text { Muriel } \\
\text { Rabilloud, } \\
\text { MD, PhD }\end{array}$ & $\begin{array}{l}\text { Hospices Civils de Lyon, } \\
\text { Lyon, France; Université }\end{array}$ & $\begin{array}{l}\text { Conception and design of } \\
\text { the study; analysis of the } \\
\text { Claude Bernard Lyon 1, drafting of the } \\
\text { manuscript; and revision } \\
\text { of the manuscript for } \\
\text { important intellectual } \\
\text { content }\end{array}$ \\
& & \\
\end{tabular}

\begin{tabular}{|c|c|c|}
\hline $\begin{array}{l}\text { Jérôme } \\
\text { Honnorat, } \\
\text { MD, PhD }\end{array}$ & $\begin{array}{l}\text { Hospices Civils de Lyon, } \\
\text { Lyon, France; Université } \\
\text { Claude Bernard Lyon 1, } \\
\text { Lyon, France }\end{array}$ & $\begin{array}{l}\text { Conception and design of } \\
\text { the study; acquisition of } \\
\text { the data; drafting of the } \\
\text { manuscript; and revision } \\
\text { of the manuscript for } \\
\text { important intellectual } \\
\text { content }\end{array}$ \\
\hline
\end{tabular}

\section{References}

1. Graus F, Delattre JY, Antoine JC, et al. Recommended diagnostic criteria for paraneoplastic neurological syndromes. J Neurol Neurosurg Psychiatry 2004;75: 1135-1140.

2. Graus F, Titulaer M, Ramani B, et al. A clinical approach to diagnosis of autoimmune encephalitis. Lancet Neurol 2016;15:391-404.

3. Dalmau J, Gleichman AJ, Hughes EG, et al. Anti-NMDA-receptor encephalitis: case series and analysis of the effect of antibodies. Lancet Neurol 2008;7:1091-1098.

4. Finke C, Kopp U, Pruss H, Dalmau J, Wandinger K, Ploner C. Cognitive deficits following anti-NMDA receptor encephalitis. J Neurol Neurosurg Psychiatry 2012;83: 195-198.

5. Hébert J, Day GS, Steriade C, Wennberg RA, Tang-Wai DF. Long-Term cognitive outcomes in patients with autoimmune encephalitis. Can J Neurol Sci 2018;45: 540-544.

6. Irani S, Stagg C, Schott J, Rosenthal C, Schneider S, Pettiingill P. Faciobrachial dystonic seizures: the influence of immunotherapy on seizure control and prevention of cognitive impairment in a broadening phenotype. Brain 2013;136:3151-3162.

7. Cohen J, Sotoca J, Gandhi S, et al. Autoimmune encephalitis: a costly condition. Neurology 2019;2:e964-e972.

8. Vogrig A, Gigli GL, Segatti S, et al. Epidemiology of paraneoplastic neurological syndromes: a population-based study. J Neurol 2020;267:26-35.

9. Dubey D, Pittock SJ, Kelly CR, et al. Autoimmune encephalitis epidemiology and a comparison to infectious encephalitis. Ann Neurol 2018;83:166-177.

10. Sonderen A, Thijs R, Coenders E, et al. Anti-LGI1 encephalitis: clinical syndrome and long-term follow-up. Neurology 2016;87:1449-1456.

11. Wright $\mathrm{S}$, Hacohen $\mathrm{Y}$, Jacobson L, et al. N-methyl-D-aspartate receptor antibodymediated neurological disease: results of a UK-based surveillance study in children. Arch Dis Child 2015;100:521-526.

12. Ho AC-C, Chan SH-S, Chan E, et al. Anti-N-methyl-d-aspartate receptor encephalitis in children: incidence and experience in Hong Kong. Brain Dev 2018;40: 473-479.

13. Déchelotte B, Muñiz-Castrillo S, Joubert B, et al. Diagnostic yield of commercial immunodots to diagnose paraneoplastic neurologic syndromes. Neurol Neuroimmunol Neuroinflamm 2020;7:e701. doi:10.1212/NXI.0000000000000701.

14. Muñiz-Castrillo S, Vogrig A, Joubert B, et al. Transient neurological symptoms preceding cerebellar ataxia with glutamic acid decarboxylase antibodies. Cerebellum 2020;10.1007/s12311-020-01159-x. doi:10.1007/s12311-020-01159-x.

15. Lancaster E, Martinez-Hernandez E, Dalmau J. Encephalitis and antibodies to synaptic and neuronal cell surface proteins. Neurology 2011;77:179-189.

16. Lancaster E. The diagnosis and treatment of autoimmune encephalitis. J Clin Neurol 2016;12:1-13.

17. Hill C, Doyon F. Âge en années révolues ou âge atteint dans l’année. Rev Epidemiol Sante Publique 2005;53:205-208. 
18. Wolfinger R, O'connell M. Generalized linear mixed models a pseudo-likelihood approach. J Stat Comput Simulation 1993;48:233-243.

19. Durrleman S, Simon R. Flexible regression models with cubic splines. Stat Med 1989; 8:551-561.

20. Wickham H. ggplot2: Elegant Graphics for Data Analysis. New York: Springer-Verlag; 2016.

21. Bivand R, Keitt T, Rowlingson B. rgdal: Bindings for the "Geospatial" Data Abstraction Library. R package 1.4-4 [online]. 2019. Available at: CRAN.R-project.org/ package $=$ rgdal. Accessed June 6, 2019.

22. Robinson R, Hayes A. Broom: Convert Statistical Analysis Objects into Tidy Tibbles. R package version 0.5.2 [online]. 2019. Available at: CRAN.R-project.org/package=broom. Accessed June 6, 2019.
23. Vogrig A, Muñiz-Castrillo S, Joubert B, et al. Central nervous system complications associated with immune checkpoint inhibitors. J Neurol Neurosurg Psychiatry 2020;91:772-778.

24. Dubey D, David WS, Amato AA, et al. Varied phenotypes and management of immune checkpoint inhibitor-associated neuropathies. Neurology 2019;93: e1093-e1103.

25. Mongay-Ochoa N, Vogrig A, Muñiz-Castrillo S, Honnorat J. Anti-Hu-associated paraneoplastic syndromes triggered by immune-checkpoint inhibitor treatment. J Neurol 2020;267:2154-2156.

26. Vogrig A, Fouret M, Joubert B, et al. Increased frequency of anti-Ma2 encephalitis associated with immune checkpoint inhibitors. Neurol Neuroimmunol Neuroinflamm 2019;6:e604. doi:10.1212/NXI.0000000000000604. 


\section{Neurology ${ }^{\odot}$ \\ Neuroimmunology \& Neuroinflammation}

Epidemiology of paraneoplastic neurologic syndromes and autoimmune encephalitides in France

Julien Hébert, Benjamin Riche, Alberto Vogrig, et al.

Neurol Neuroimmunol Neuroinflamm 2020;7;

DOI 10.1212/NXI.0000000000000883

This information is current as of August 26, 2020

Neurol Neuroimmunol Neuroinflamm is an official journal of the American Academy of Neurology.

Published since April 2014, it is an open-access, online-only, continuous publication journal. Copyright

Copyright $\odot 2020$ The Author(s). Published by Wolters Kluwer Health, Inc. on behalf of the American

Academy of Neurology.. All rights reserved. Online ISSN: 2332-7812.

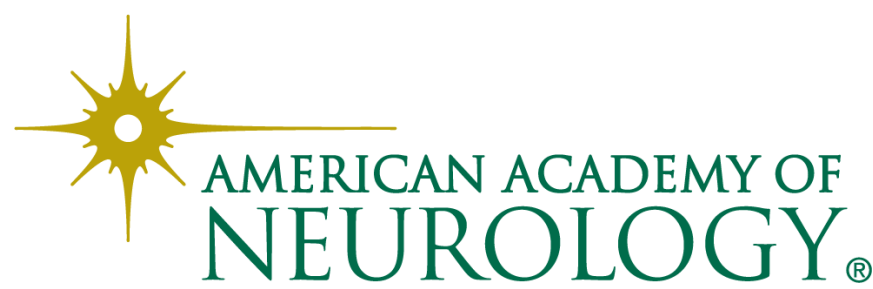




\section{Updated Information \& Services}

References

Citations

Subspecialty Collections

Permissions \& Licensing

Reprints including high resolution figures, can be found at: http://nn.neurology.org/content/7/6/e883.full.html

This article cites 23 articles, 6 of which you can access for free at: http://nn.neurology.org/content/7/6/e883.full.html\#\#ref-list-1

This article has been cited by 5 HighWire-hosted articles: http://nn.neurology.org/content/7/6/e883.full.html\#\#otherarticles

This article, along with others on similar topics, appears in the following collection(s):

Autoimmune diseases

http://nn.neurology.org//cgi/collection/autoimmune_diseases Encephalitis

http://nn.neurology.org//cgi/collection/encephalitis

Incidence studies

http://nn.neurology.org//cgi/collection/incidence_studies

Paraneoplastic syndrome

http://nn.neurology.org//cgi/collection/paraneoplastic_syndrome

Information about reproducing this article in parts (figures,tables) or in its entirety can be found online at:

http://nn.neurology.org/misc/about.xhtml\#permissions

Information about ordering reprints can be found online:

http://nn.neurology.org/misc/addir.xhtml\#reprintsus

Neurol Neuroimmunol Neuroinflamm is an official journal of the American Academy of Neurology.

Published since April 2014, it is an open-access, online-only, continuous publication journal. Copyright

Copyright $\odot 2020$ The Author(s). Published by Wolters Kluwer Health, Inc. on behalf of the American

Academy of Neurology.. All rights reserved. Online ISSN: 2332-7812.

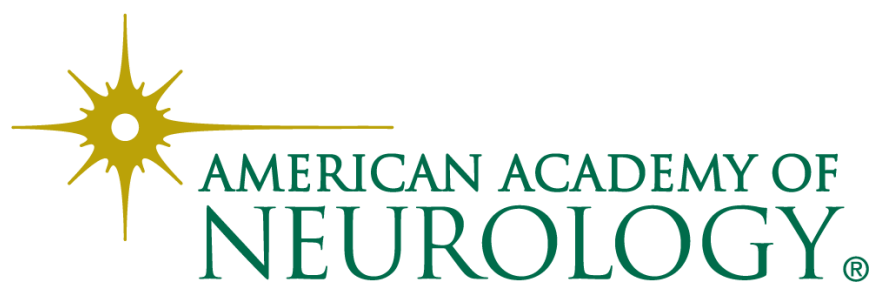

